\title{
Genre Based Approach in Teaching Writing Analytical Exposition Text
}

\author{
Erni Yulianti \\ Graduate Program of English Department, Lampung University \\ e-mail:ernismansa@gmail.com
}

received : 21 February 2017

accepted : 10 April 2017

published : April 2017

\begin{abstract}
Genre based approach in teaching writing analytical exposition text.This study investigated the Genre-Based Approach (GBA) in teaching writing the analytical exposition text. This study tried to describe GBA application in the class, to know how GBA led to students' writing analytical exposition text, and to know students' perception toward GBA in writing analytical exposition text. Data in this study were obtained from questionnaires and pretest-post test. Data from pretest-post test, to know the improvement of the students' writing analytical exposition text were administered by using Match T-test. The finding revealed that students had positive perception in learning writing analytical exposition text through GBA.
\end{abstract}

Keywords: genre based approach, writing analytical exposition text, teaching writing.

Abstrak: Pendekatan berbasis genre (GBA) pada pengejaran menulis teks eksposisi analisis Penelitian ini mencoba untuk menggambarkan penerapan GBA di kelas, untuk mengetahui bagaimana GBA mempermudah siswa dalam menulis teks eksposisi analitis, dan untuk mengetahui tanggapan siswa terhadap GBA dalam menulis teks eksposisi analitis. Data dalam penelitian ini diperoleh dari kuesioner dan uji pre-post tes. Data dari uji pre dan post tes untuk mengetahui peningkatan siswa dalam menulis teks eksposisi analisis yang diberikan dengan menggunakan perbandingan T-test. Penelitian menunjukkan bahwa siswa memiliki persepsi positif dalam belajar menulis teks eksposisi analitis melalui pendekatan GBA.

Kata kunci: pendekatan genre-based, menulis teks analytical eksposisi, mengajar writing. 


\section{INTRODUCTION}

This study concerns in teaching writing analytical exposition text through genre-based approach. Understanding genre in writing is necessary. Harmer stated, "We can communicate successfully, especially in writing, is because we have some understanding of genre" (Harmer, 2007: 30). Teaching writing was explicitly stated in senior high school curriculum (Law of Republic of Indonesia Ministry of Education Article 22, 2006).

Senior high school curriculum was developed from time to time. Competence Base Curriculum known as KBK (Kurikulum Berbasis Kompetensi) was implemented from 2004 to 2006. Then, School-Base Curriculum (KTSP) implemented from 2006 to 2012. Finally, curriculum 2013 was implemented in July 2013. When curriculum was developed-considered as adaptation for recent educational paradigm-then, teacher who used the curriculum need to provide effective teaching as part of curriculum development (Richards, 2001 quoted in Aisah, 2009)

A genre-based approach placed great emphasis on the relationship between text-genres and their contexts. In doing so, it aimed to help students become effective participants in their academic and professional environment as well as in their broader communities. Genre as an approach to language teaching referred to "grouping text together" those writers used to counter to recurring situation (Hyland, 2007: 4). Moreover, Teaching writing coincided with those of other language skills; listening, speaking and reading (Brown, 2001; 334), genre played an important role in teaching writing as Harmer stated, "we can communicate successfully, especially in writing, is because we have some understanding of genre. (Harmer, 2007: 30). Moreover, "we judge people as literate, in other words, if they can read and write in certain situation and for certain purpose (Harmer, 2007: 323). Then, Genre defines "as written text" to the demands of social context (John, 2002:3).

The following are some characteristics of the genre-based approach. First, the genre-based approach emphasizes the importance of exploring the social and cultural context of language use on a piece of writing. The context decides the purpose of a text, an overall structure of a text in terms of language features and text features. This approach argues that students can only produce a composition to be successfully accepted by a particular English-language discourse community once they take the context of a text into account into their own writing papers.

Second, this approach highlights the magnitude of the readers and the linguistic conventions that a piece of writing needs to follow in order to be successfully accepted by its readership. According to this approach, any student who wants to be successful in communicating in a particular English-language discourse community needs to be able to produce texts that fulfill the expectations of their readers in regards to grammar, organization, and content.

Third, it underscores that writing is a social activity. This notion originated from the social cultural theory initiated. According to this theory, knowledge is best constructed when learners collaborate, support one another to encourage new ways to form, construct and reflect on new knowledge. In this case, social interactions and participation of group members play a key role in developing new knowledge. In the writing classes, students are encouraged to participate in the activities of meaning exchange and negotiation with peers and the teacher. Learning writing in this way, it can remove the feeling of isolation that bothers many learners when writing and, at the same time, help student writers have positive reinforcements about the knowledge of linguistics, content and ideas in the composing of texts. 
Fourth, a genre-based approach to writing instruction looks beyond subject content, composing processes and linguistic forms to see a text as attempts to communicate with readers. This approach is concerned with teaching learners how to use language patterns to accomplish coherent, purposeful prose writing. Its belief that we do not just write, we write something to achieve some purpose. In this approach, the students are requested to take the overall social purposes of a text into account when composing a text.

Fifth, this approach emphasizes the important role of writer-reader interaction on a piece of writing. Firstly, student writer in this approach is requested to specify or think about the intended and/or potential readers when writing in order to be able to select or anticipate appropriate content, language and levels of formality. He or she should always ask himself or herself some questions such as who will be my intended readers. Who might be interested in reading my text? What are their beliefs about a good piece of writing? What are their levels of English proficiency? In addition, what are their educational and cultural backgrounds? Etc. Similarly, readers when approaching the text should also ask themselves some questions such as for what purposes does this writer write this piece of writing. What is the writer's viewpoint when writing the text? What kinds of language features and organization does he/she use in the text? In addition, etc. In addition, there always exists an interaction between a writer and his/her readers in the form of written communication despite the absence of readers.

Sixth, the teacher's role in this approach is viewed as authoritative rather than authoritarian. As an expert in the classroom, the teacher provides students with systematic guidance and careful support through various activities so that students ultimately gain the control of written genres. At the same time, he/she also recognizes the importance of students' contributions to the teaching-learning process.

Finally, the genre-based approach emphasizes the explicit teaching of the linguistic conventions of the genre for second language student. It is argued that students cannot produce a particular text-type successfully if they are not taught explicitly about linguistic conventions of that text-type with respect to language features and schematic structure. Therefore, making known these conventions to student writers, especially at the first stage of the instructional modules of particular text-types, is a very important task of genre-based teachers. In the classroom, teachers following genre orientation often employ the teaching-learning cycle that comprises the three phases, namely, modeling of a -sample expert" text, and joint-negotiation of text with teacher, and independent construction of text by individual student.

It was explicitly stated on The National Curriculum, so called, as school-based curriculum that various genres were parts of senior high school curriculum materials that students learned (Law of Republic of Indonesia Ministry of Education Article 22, 2006). Therefore, this study focused on students' perception in learning writing a analytical exposition, students' perception in using technology through genre-based approach and how genre-based approach gave impact to the students' writing analytical exposition.

There were four cycles suggested in teaching writing through genre-based approach; they were "building knowledge of the field", "modeling of the text", "joint construction", and "independent construction" (Gibbons 2002:6061 quoted in Nisak, 2008). Teacher of English needed to know these cycles and implement those when teaching writing through genre-based approach.

To minimize students' difficulties in learning writing skill for EFL students, implementing genre-based approach in teaching writing 
analytical exposition text gave alternative solution since genre based approach built students' knowledge, in such key points as; generic structures, appropriate linguistic choices, explicit grammar, sentence structures which enabled students to write a similar text in the next stage. This activity, so-called modeling text, is a "scaffolding activity that involves teacher and learners discussing and exploring the stages of the genre and its key grammatical and rhetorical features" In this stage, the teacher gave "representative sample of the target genre" (Hyland, 2007: 132).

Recent studies showed that genre base approach brought benefit in teaching writing (Tuan, 2011; Yang, 2012; Nisak, 2008). Genrebased approach also enhanced students writing ability as Belcher stated, "Using the genre-based approach is its high face validity due to the fact that students are writing papers on topics that they are researching. It was helping them improve their ability to complete their written assignments successfully" (Belcher: 11).

Trying to fill the two gaps on (1) The effectiveness GBA for the students in teaching writing.The notion of GBA emphasizes the role of interaction with peers and with experienced others in learning In additional, (2) to minimize students' difficulties in learning writing skill for EFL students (Richards, 1990 quoted in Tuan, 2011) in such ways " (1) generating and organizing ideas using an appropriate choice of vocabulary, sentence and paragraph organization and (2) putting such ideas into an intelligible text" (Tuan, 2011: 1). This research report concern on the effectiveness GBA in teaching writing analytical exposition text to help the students in writing the analytical exposition text.

\section{METHOD}

This research used pre-experimental design to know genre-based approach had an effect in teaching analytical exposition text. The one-group pretest-posttest design was used in this study. The population of the study was the second grade of Senior High School in Pangkalpinang, Bangka Belitung Province. The second year students were chosen since writing analytical exposition text was learned by the students of the first semester of the second year based on curriculum developed at the school. There were seven classes of eleven grade students. Every class contained thirtystudents. Then, one group from seven classes was assigned to be the research sample. The simple random sample was assigned to obtain the sample from the population randomly.

The design of the research was as follow:

$$
\begin{aligned}
& \mathrm{T}_{1} \times \mathrm{T}_{2} \\
& \mathrm{~T}_{1}=\text { pretest } \\
& \mathrm{X}=\text { treatment } \\
& \mathrm{T}_{2}=\text { posttest }
\end{aligned}
$$

The pretest was administered to know the students writing analytical exposition text ability. Then, the teacher gave the students treatments for eight times within a month and ended by giving the posttest. Pretest and posttest were administered. They were essay-writing tests. The students were given a prompt. Then, they responded the prompt into analytical exposition text essay. The students did the pretest or posttest in one hour. The pretest was administered before the treatments. The writing cycles were administered in classroom teaching-learning activities. Next, the posttest was administered. Then, continued by administering the questionnaires. All the activities were conducted in the classroom.

There are learning procedures GBA in teaching writing analytical exposition text. 
a. Building knowledge of the topic

In this first stage, teacher built students' knowledge on the field of the meaning work in context, students' awareness of the social purpose of genres, (Hyland, 2007: 130) that later, those activities on the first stage led the students to gain enough background knowledge of the topic as a base understanding for the next steps. The activities in this stage will involve such as "speaking, listening, reading, information gathering, and note taking" (Nisak, 2008: 13).

\section{b. Modeling text}

The second stage, modeling text is a "scaffolding activity that involved teachers and learners discussing and exploring the stages of the genre and its key grammatical and rhetorical features." In this stage, the teacher gave "representative sample of the target genre" (Hyland, 2007: 132). In addition, teacher assisted the students to focus on the genre features analyzed, such as generic structures, appropriate linguistic choices, explicit grammar, sentence structures that enable students to write a similar text in the next stage.

\section{c. Joint construction}

Teacher and students constructed a target genre together as a whole-class activity. The activity led students to know the written text. The main purpose was to illustrate on the target genre writing process leads to content and linguistic choices. The teacher "ask students to work in group to produce parallel text" while the teacher's role is as learners' facilitator. Then, teacher "gradually reducing his or her contribution as learners gains greater control over their writing" (Hyland, 2007: 136).

d. Independent writing

The fourth stage let the students to write a target text independently to apply what they had learned "while the teacher looks on and gives advice from the sidelines." The independent construction as the final stage on the writing cycle regard as the "core of writing instruction" and it was likely to be more productive when there was scaffolding activity such as drafting, self-editing, and discussing (Hyland, 2007: 136-137). Then, utilizing Grammarly greatly helped students in selfediting stages.

Table 1. Tests of Normality

\begin{tabular}{lcccccc}
\hline & \multicolumn{3}{c}{ Kolmogorov-Smirnov $^{\mathbf{a}}$} & \multicolumn{3}{c}{ Shapiro-Wilk } \\
\cline { 2 - 7 } & Statistic & Df & Sig. & Statistic & Df & Sig. \\
\cline { 2 - 7 } Pretest & .127 & 30 & $.200^{*}$ & .972 & 30 & .599 \\
Posttest & .107 & 30 & $.200^{*}$ & .939 & 30 & .086 \\
\hline
\end{tabular}

a. Lilliefors Significance Correction

*. This is a lower bound of the true significance.

Table 2. The Levene's test and t-test between pretest and posttest Group Statistics

\begin{tabular}{lccccc}
\hline & \multicolumn{5}{c}{ Group Statistics } \\
\cline { 2 - 6 } & Group & $\mathrm{N}$ & Mean & $\begin{array}{c}\text { Std. } \\
\text { Deviation }\end{array}$ & $\begin{array}{c}\text { Std. Error } \\
\text { Mean }\end{array}$ \\
\cline { 2 - 6 } Pretest \& & Pretest & 30 & 45.3667 & 13.73012 & 2.50676 \\
posttest & Posttest & 30 & 62.7667 & 9.48932 & 1.73250 \\
\hline
\end{tabular}


Table 3. Independent Samples Test

\begin{tabular}{|c|c|c|c|c|c|c|c|c|c|c|}
\hline & & \multicolumn{2}{|c|}{$\begin{array}{c}\text { Equality of } \\
\text { Variances }\end{array}$} & \multicolumn{7}{|c|}{ t-test for Equality of Means } \\
\hline & & $\mathrm{F}$ & Sig. & \multirow[t]{2}{*}{$\mathrm{T}$} & \multirow[t]{2}{*}{ Df } & \multirow[t]{2}{*}{$\begin{array}{l}\text { Sig.(2- } \\
\text { tailed) }\end{array}$} & \multirow[t]{2}{*}{$\begin{array}{c}\text { Mean } \\
\text { Difference }\end{array}$} & \multirow[t]{2}{*}{$\begin{array}{l}\text { Std. Error } \\
\text { Difference }\end{array}$} & \multicolumn{2}{|c|}{$\begin{array}{l}\text { 95\% Confidence } \\
\text { Interval of the } \\
\text { Difference }\end{array}$} \\
\hline & & & & & & & & & Lower & Upper \\
\hline \multirow[t]{2}{*}{$\begin{array}{c}\text { Pretest } \\
\& \\
\text { posttest }\end{array}$} & $\begin{array}{l}\text { Equal } \\
\text { variances } \\
\text { assumed }\end{array}$ & 2.887 & .095 & -5.710 & 58 & .000 & -17.400 & 3.04720 & -23.499 & -11.300 \\
\hline & $\begin{array}{l}\text { Equal } \\
\text { variances } \\
\text { not assumed }\end{array}$ & & & -5.710 & 51.55 & .000 & -17.400 & 3.04720 & -23.515 & -11.284 \\
\hline
\end{tabular}

\section{RESULT AND DISCUSSION}

a. Genre-based approach improve students' writing analytical exposition text

Before the t-test was used to compare the means of pretest and posttest, Kolmogorov Smirnov test was utilized to find out the normality distribution of pretest. The calculation using Kolmogorov Smirnov test was as follow.

When significant (Sig.) is higher than 0.05, the distribution of pretest is normal. In contrast, when significant (Sig.) is less than 0.05, the distribution of pretest is not normal. From table 1, the data showed that the significant (Sig.) of pretest was 0.200 which was higher than 0.05 . It meant that the distribution scores of pretest were normal. Then, to know the homogeneity of variance, the researcher administered Levene Test (Table 2).

The criterion of homogenous variance is when the probability is higher than $0.05(\mathrm{p}>0.05)$, while if the probability is less than $0.05(\mathrm{p}<0.05)$, the variance is not homogenous. The data showed that the significance value (Sig.) was 0.095 (Table 3 ) was higher than 0.05 ( $>>0.05)$. In conclusion, the sample of the population was homogenous.

The table provided the result from pretest and posttest. It showed that $\mathrm{t}$-count $=5.710$. The $\mathrm{t}$-table with $(\mathrm{df}=\mathrm{N}-1)$, at level of significance a $=0.05$ was 2.045 . The table showed that $\mathrm{t}$-count was higher than t-table. Therefore, genre-based approach improved students' writing analytical exposition text.
Table. 4. Students' Perception in Learning Writing Analytical exposition text Through Genre-Based Approach

\begin{tabular}{|c|c|c|}
\hline \multirow{2}{*}{$\begin{array}{c}\text { Perception } \\
\text { Categories }\end{array}$} & \multicolumn{2}{|c|}{ Students' Perception } \\
\cline { 2 - 3 } & $\begin{array}{c}\text { Number of } \\
\text { Respondents }\end{array}$ & Percentage \\
\hline \multirow{2}{*}{ Positive } & 29 & 9 \\
& & $\begin{array}{l}7 \\
\%\end{array}$ \\
\hline Neutral & 1 & 3 \\
\hline Negative & - & - \\
\hline & & 1 \\
Total & 30 & 0 \\
Respondents & & 0 \\
& & \\
\hline
\end{tabular}

b. Genre-based approach leads to students' perception in learning writing analytical exposition text.

The data from table 4 showed that 29 or (97\%) students had positive perception in learning writing analytical exposition text through genrebased approach while 1 or $(3 \%)$ students' perception in learning writing analytical exposition text through genre-based was neutral.

The students understood the text explained by teacher ( 29 students) while ( 28 students) claimed that learning analytical exposition text through genre-based was enjoyable. Understanding genre based, the students felt easier in producing analytical exposition text $(28$ 
students). Then, scaffolding played an important role in writing cycles (27 students). Wash back was needed by students on their writing ( 28 students) to motivate them to revise their writing (29 students).

\section{CONCLUSION}

The study found that genre-based approach improved students' writing analytical exposition text of the first grade of the second year at one of Senior High Schools in Pangkalpinang. In addition, the implementing of GBA benefited the students in writing cycles into analytical exposition text. Therefore, these findings may be beneficial for students, educators or writing instructor's text in teaching analytical exposition text through Genre Based approach and by understanding genre based, the students felt that it made them easier to produce analytical exposition text since pair and group discussion played an important role in writing cycles (Hyland, 2007: 136-137 and Harmer, 2007: 30).

Moreover, the data showed that 28 or (93\%) students had positive perception in implementing the GBA in learning writing analytical exposition text. The students thought that the GBA helped them in writing process. GBA had the right steps to assist and do discussion with the other students in writing so that the students were motivated to revise their work. In other words, they had more practices in writing (fill the absence of little exercise in writing as stated by (Alwasilah 2000: 108 quoted in Herawati 2009).

Based on these findings, it is recommended that genre-based approach be implemented in teaching writing analytical exposition text and there was needed more investigation on the usage of Grammarly, an online rater, to judge the students recount writing text compared with the writing analytical exposition text scoring rubric suggested by experts.

\section{REFERENCES}

Aisiah. E.E (2009). Development of English Language Teaching Syllabus in Indonesia, A Journal Retrieved from http://englisah. wordpress.com/2009/05/ 11/development-of-english-languageteaching-syllabus-in-indonesia/

Azwar. S. (2012). Penyusunan Skala Psikologi. Pustaka pelajar.

Belcher. D. (...). Effectiveness of the Genrebased Approach for Graduate Students. Georgia State University.

Brown, H.D. (2001). Teaching by Principles; An Interactive Approach to Language pedagogy. Second edition, San Francisco State university. Addison Wesley Longman, Inc.

Cresswell, John W. (2008). Educational Research, Planning, Conducting, and Evaluating Quantitative Qualitative Research. Third Edition. New Jersey: Pearson Education, Inc.

Harmer. J. (2007). The Practice of English Language Teaching. Fourth Edition. Pearson Longman.

Herawati. N. (2009). An Investigation on the Implementation of a Genre-Based Approach. (AScript, Indonesia University of Education, 2009, Unpublished)

Hylan. K. (2007). Genre and Second Language Writing. Michigan Series in Teaching Multilingual Writers. The university of Michigan.

Johns.M.A. (2002). Genre in the Classroom; Multiple Perceptions. Lawrence Erlbaum Associates, Publiser. Mahwah, New

Standar

Competence and Base Competence for Primary and Senior High School. 
Nisak. K. (2008). The Genre basedd approach to teaching a recount Genre. (A Script, Indonesia University of Education, 2008, Unpublished)

Tuan. L.T. (2011). Teaching Writing through Genre-Based Approach. Theory and Practice in Language Studies, Vol. 1, No. II, pp.147-1478, November 2011 (C) 2011 ACADEMY PUBLISHER
Manufactured in Finland. Doi:10.4304/ tpls.1.11.1471-1478.

Yang. W. (2012). A study of Students' Perceptions and Attitudes towards Genre-Based ESP Writing Instruction. Asian ESP Journal. National Kaohsiung University of Hospitality and Tourism, Taiwan. Volume 8 Issue 3 Autumn 2012. 